\title{
Initial Substrate Moisture Content and Storage Temperature Affect Chemical Properties of Bagged Substrates Containing Poultry Litter Fertilizer
}

\author{
James E. Altland ${ }^{1,3}$ \\ USDA-ARS, Application Technology Research Unit, Ohio Agricultural \\ Research and Development Center, 1680 Madison Avenue, Wooster, OH \\ 44691

\section{Ka Yeon Jeong ${ }^{2}$ \\ Department of Horticulture and Crop Science, The Ohio State University, 2021 Coffey Road, Columbus, OH 43210}

Additional index words. electrical conductivity, microbial activity, nitrate, nitrogen immobilization, nutrient release, $\mathrm{pH}$, phosphate, potassium

\begin{abstract}
Bagged potting mixes can be stored for weeks or months before being used by consumers. Some bagged potting mixes are amended with organic fertilizers such as poultry litter (PL), although there is little knowledge about how these and other organic fertilizers release in the substrate while in storage. The objective of this research was to determine nutrient availability from an organic PL fertilizer in a bagged potting substrate stored at different temperatures and with varying initial moisture content (IMC). The base substrate composed of 60 sphagnum peat : 30 bark : 10 perlite (by vol.) amended with $5.5 \mathrm{~g} \cdot \mathrm{L}^{-1}$ dolomitic limestone and $0.5 \mathrm{~g} \cdot \mathrm{L}^{-1}$ granular wetting agent. This base substrate was either not amended with additional fertilizer [nonfertilized control (NFC)] or amended with a PL fertilizer (microSTART60, 3N-0.9P-2.5K) in its original pelletized form (PL-P) or ground (PL-G), or an uncoated prill fertilizer (UPF, 15N-6.5P$12.5 \mathrm{~K}$ ). Substrates had IMCs of $25 \%, 45 \%$, or $65 \%$ (by weight) and were stored at either 20 or $40^{\circ} \mathrm{C}$. The UPF treatment resulted in lower $\mathrm{pH}$, higher electrical conductivity (EC), and higher percent recovered nitrogen $(N)$ compared with other treatments, as was expected with a readily soluble fertilizer. Poultry litter particle size had no effect on any of the measured chemical properties of the stored substrates. Both PL fertilizer treatments resulted in $\mathrm{pH}$ similar to or lower than the NFC. The two PL fertilizers had higher EC throughout the experiment $\left(1.59-2.76 \mathrm{mS} \cdot \mathrm{cm}^{-1}\right)$ than NFC $(0.13-0.35$ $\left.\mathrm{mS} \cdot \mathrm{cm}^{-1}\right)$. Poultry litter fertilizer provided a stable source of $\mathrm{N}$ in bagged potting $\mathrm{mix}$ over a range of IMC and storage temperatures, with little change in total $\mathrm{N}$ released over time.
\end{abstract}

There is increasing demand from consumers and mass merchant retailers for products that are organic, more sustainable, or have lower carbon footprints. Consumer demand for organic gardening products is being driven primarily by increased demand from younger consumers for edible gardening and related products (Granderson, 2015). This demand includes bagged potting mixes. In the previously cited market study (Granderson, 2015), $30 \%$ of respondents who purchased organic gardening products specifically purchased "organic soil." Mass merchants are also seeking to reduce their carbon footprint by demanding greater sustainability from their supply chain (Anonymous, 2017)

Received for publication 23 Feb. 2018. Accepted for publication 28 May 2018

${ }^{1}$ Research Horticulturist.

${ }^{2}$ Research Assistant.

${ }^{3}$ Corresponding author. E-mail: james.altland@ ars.usda.gov. used substrate components are eligible for organic labels, including peat, perlite, vermiculite, and coir (Wander, 2015). Providing an organic source of nutrition in bagged potting mixes is more difficult. Many organic nutrient sources are not immediately available for plant uptake. Organic fertilizers in substrates can come from many sources, although all can be categorized under three broad categories including plant-based fertilizers, animal-based sources, including manures, and some mined sources (Burnett et al., 2016).

Organic fertilizers have been used in soilless substrates and container production. Bi et al. (2010) showed that container-grown marigolds (Tagetes patula L.) with $1 \%$ to $2 \%$ (by vol.) broiler litter fertilizer had similar growth, flowering, and foliar nutrient concentrations as those grown with traditional controlled release fertilizer (CRF). Likewise, Mattson (2014) compared the production of several greenhouse crops in $10-\mathrm{cm}$ pots using a traditional liquid feed program with three granular organic fertilizers preincorporated into the substrate and concluded that the organic fertilizers provided sufficient nutrients for these greenhouse crops and shortened the production periods. However, these studies and other authors (Fisher et al., 2016) warn that $\mathrm{N}$ mineralization from organic fertilizers is difficult to predict; and thus, managing fertility over time can be problematic.

Substrate moisture and temperature are two important factors affecting $\mathrm{N}$ availability from organic fertilizers. Griffin and Honeycutt (2000) used growing degree-day models to accurately predict $\mathrm{N}$ mineralization from poultry and other manure types in a sandy loam soil, demonstrating the importance of temperature on $\mathrm{N}$ mineralization rates. Malhi and McGill (1982) likewise showed reduced soil moisture and reduced nitrification in three different field soils; the highest rate of mineralization occurred with soil matric potential of $-33 \mathrm{kPa}$ and declined but did not stop at $-1500 \mathrm{kPa}$. Numerous other studies have documented the effects of soil moisture and temperature on $\mathrm{N}$ mineralization in components, developing organic pot mixes is relatively easy, as most commonly $20^{\circ} \mathrm{C}$

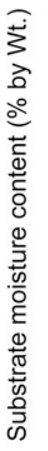

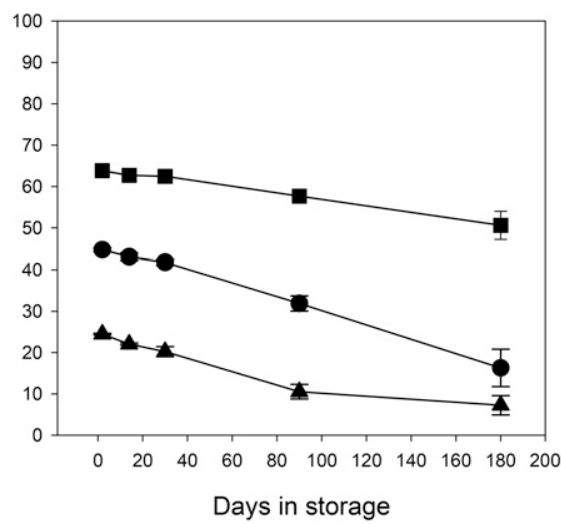

$40^{\circ} \mathrm{C}$

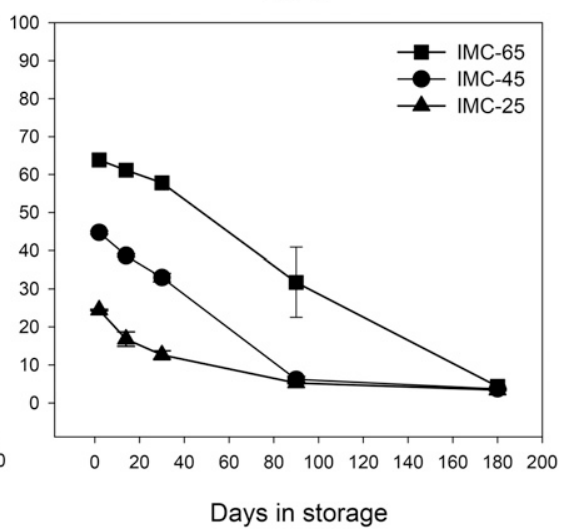

Fig. 1. Moisture content (\%, by weight) of the bagged substrates stored in a growth chamber set to 20 (left) and $40{ }^{\circ} \mathrm{C}$ (right) during a 180-d storage period. Error bars represent the $95 \%$ confidence interval about the mean. $\mathrm{IMC}=$ initial moisture content. 
soils, as reviewed by Agehara and Warncke (2005). However, virtually all of the $\mathrm{N}$ mineralization research has been conducted on field soils, where mineralization rates are also dependent on the inherent chemical and physical properties of each soil type (Chae and Tabatabai, 1986). Research on the mineralization of $\mathrm{N}$ from organic fertilizers in soilless substrates is lacking. Therefore, the objective of this research was to determine nutrient availability from an organic PL fertilizer in a bagged potting substrate stored at different temperatures and with varying IMC.

\section{Materials and Methods}

The base substrate was 60 sphagnum peat: 30 aged pine bark fines: 10 perlite (by vol.) amended with $5.5 \mathrm{~g} \cdot \mathrm{L}^{-1}$ dolomitic limestone (ECOPHRST; National Lime and Stone Co., Findlay, $\mathrm{OH}$ ) and $0.5 \mathrm{~g} \cdot \mathrm{L}^{-1}$ granular wetting agent (AquaGro 2000G; Aquatrols, Paulsboro, NJ). The treatment design was a $3 \times 4$ factorial arrangement with three moisture levels and four fertilizer treatments. Water was added to the base substrate to attain IMC of $25 \%, 45 \%$, or $65 \%$, calculated as the mass of water per mass of wet substrate.

The fertilizer treatments included the base substrate described previously with lime and wetting agent only as a NFC, a PL fertilizer (microSTART60, 3N-0.9P-2.5K; PerdueAgriBusiness LLC., Seaford, DE) in its original pelletized form (PL-P) or ground (PL-G) or an (UPF, 15N-6.5P-12.5K; Yara, Oslo, Norway). The prills for the PL-P fertilizer were $99 \%$ smaller than $3.36 \mathrm{~mm}$, whereas those in the PL-G were ground with a coffee grinder to be less than $1.19 \mathrm{~mm}$. To investigate the differences in the nutrient availability between organic and inorganic fertilizers, UPF is added to compare with PL treatments. All fertilizer treatments were incorporated at $0.59 \mathrm{~kg} \cdot \mathrm{m}^{-3} \mathrm{~N}$.

After fertilizer treatments were mixed into the base substrate, $0.4 \mathrm{~L}$ of each was placed in $10 \times 15 \mathrm{~cm}$, two mil sealable plastic bags (Royal Bag, Brooklyn, NY). Each bag was perforated with four holes to simulate the perforation of commercial bagged potting mixes. The bags were placed in a growth chamber (VWR Signature Diurnal Growth Chamber, Model 2015; VWR International, Radnor, PA) set to 20 or $40^{\circ} \mathrm{C}$. Because the growth chambers could not be replicated for practical reasons, differences in nutrient availability from the substrates between the two storage temperatures will not be compared statistically but will be discussed. There were four bagged replications of each fertilizer, temperature, and moisture level combination for each of five harvest dates at 2, 14, 30, 90, and $180 \mathrm{~d}$ after mixing.

Two days after the substrate treatments were mixed, but before they were placed in growth chambers for storage, four replication bags of each fertilizer and moisture treatment combination were analyzed for water extractable nutrients using a modified saturated media extraction procedure. Substrates were transferred each to a $1 \mathrm{~L}$ sealable plastic bag
Table 1. Probability values ( $P$ value) for main effects and interactions of fertilizer type $(F)$, initial moisture concentration (IMC), and day (D) of collection on the $\mathrm{pH}$, electrical conductivity (EC), inorganic nitrogen $\left(\mathrm{IN}, \mathrm{NO}_{3}{ }^{-}+\mathrm{NH}_{4}{ }^{+}\right.$), total nitrogen $(\mathrm{TN}$, all organic and inorganic water soluble $\mathrm{N})$, and phosphorus $(\mathrm{P})$ recovered in bagged substrates stored at 20 or $40{ }^{\circ} \mathrm{C}$.

\begin{tabular}{llccccc}
\hline Temperature $\left({ }^{\circ} \mathrm{C}\right)$ & & $\mathrm{pH}$ & $\mathrm{EC}$ & $\mathrm{IN}$ & $\mathrm{TN}$ & $\mathrm{P}$ \\
\hline 20 & Fertilizer type (F) & 0.0001 & 0.0001 & 0.0001 & 0.0001 & 0.0001 \\
& Initial moisture (IMC) & 0.0001 & 0.0001 & 0.0001 & 0.0001 & 0.0001 \\
& F*IMC & 0.0017 & 0.0001 & 0.0001 & 0.0001 & 0.0001 \\
& Day (D) & 0.0778 & 0.0081 & 0.0001 & 0.0001 & 0.0001 \\
& D*F & 0.7385 & 0.2762 & 0.0001 & 0.0001 & 0.0001 \\
& D*IMC & 0.0045 & 0.0015 & 0.0003 & 0.0001 & 0.0001 \\
& D*F*IMC & 0.3126 & 0.3934 & 0.0001 & 0.0075 & 0.0001 \\
40 & Fertilizer type (F) & 0.0001 & 0.0001 & 0.0001 & 0.0001 & 0.0001 \\
& Initial moisture (IMC) & 0.0001 & 0.0001 & 0.0112 & 0.0001 & 0.0001 \\
& F*IMC & 0.0001 & 0.0001 & 0.0001 & 0.0001 & 0.0001 \\
& Day (D) & 0.0001 & 0.0001 & 0.0001 & 0.0001 & 0.0001 \\
& D*F & 0.0031 & 0.0001 & 0.0001 & 0.0001 & 0.0001 \\
& D*IMC & 0.0016 & 0.0487 & 0.0263 & 0.0001 & 0.0001 \\
& D*F*IMC & 0.0001 & 0.6181 & 0.0036 & 0.0001 & 0.0001 \\
\hline
\end{tabular}

$20{ }^{\circ} \mathrm{C}$
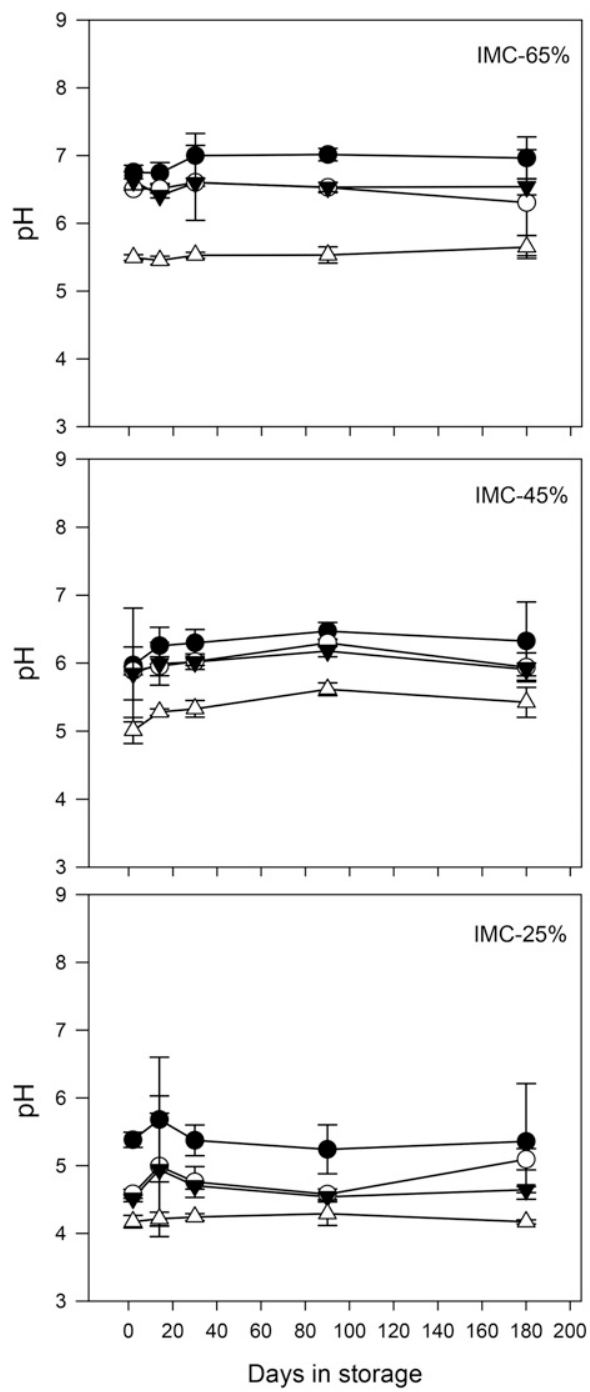

$40{ }^{\circ} \mathrm{C}$
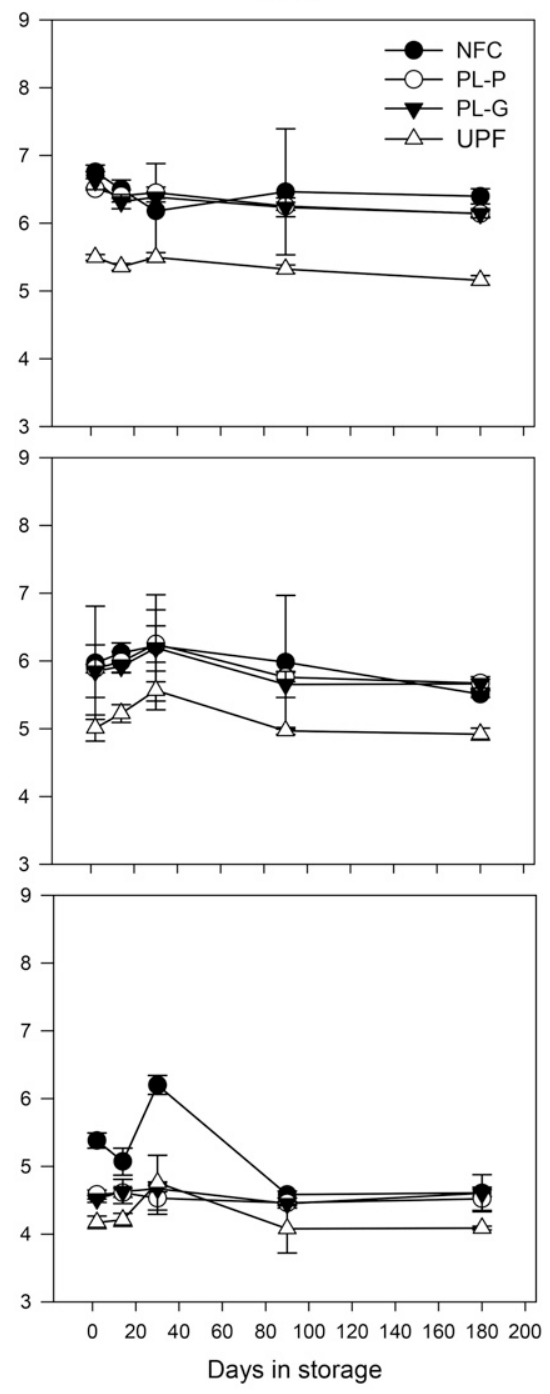

Fig. 2. Substrate $\mathrm{pH}$ of a bagged substrate composed of 60 sphagnum peat : 30 bark : 10 perlite by volume with $5.5 \mathrm{~g} \cdot \mathrm{L}^{-1}$ dolomitic limestone. Substrates were either not amended with fertilizer [(nonfertilized control (NFC)], or amended with $0.59 \mathrm{~kg} \cdot \mathrm{m}^{-3} \mathrm{~N}$ of a poultry litter (PL) (microSTART60, 3N-0.9P-2.5K) that was either pelletized (PL-P) or ground (PL-G), or amended with an uncoated prilled fertilizer (UPF, $15 \mathrm{~N}-6.5 \mathrm{P}-12.5 \mathrm{~K}$; Yara). Substrates had initial moisture contents (IMCs) of $65 \%$ (top), $45 \%$ (middle), or $25 \%$ (bottom) and were stored at either $20{ }^{\circ} \mathrm{C}$ (left) or $40{ }^{\circ} \mathrm{C}$ (right). Error bars represent a $95 \%$ confidence interval about the mean. 
and $350 \mathrm{~mL}$ of reverse osmosis water was added. The substrate slurry was allowed to come to equilibrium for $30 \mathrm{~min}$. Afterward, a small hole was cut into the corner of the bag and placed immediately over polyvinyl chloride Buchner funnels $(13.1 \mathrm{~cm}$ i.d., $6.6 \mathrm{~cm}$ tall; Thermo Fisher Scientific, Waltham, MA) fitted with a fiberglass filter paper (G6; Thermo Fisher Scientific). The Buchner funnels were attached to an Erlenmeyer flask and placed under vacuum to facilitate extraction of the water from the substrate and through the filter paper. Filtrates were immediately placed in a refrigerator and stored at $2{ }^{\circ} \mathrm{C}$ until the time of analysis.

At analysis, $\mathrm{pH}$ was determined with a $\mathrm{pH} /$ ion analyzer (MA 235; Metler Toledo, Columbus, $\mathrm{OH}$ ) and $\mathrm{EC}$ with a conductivity meter (Fisher 06-662-61; Thermo Fisher Scientific). Samples were subsequently filtered through $\mathrm{GF} / \mathrm{F}$ binder-free borosilicate glass fiber filter paper (Whatman Ltd., Kent, UK) to remove particles greater than $0.7 \mu \mathrm{m}$. The filtrate was poured into 5-mL autosampler vials, capped, and analyzed using ion chromatography (ICS 1600 Ion Chromatography System; Dionex, Bannockburn, IL) for concentrations of nitrate $\left(\mathrm{NO}_{3}^{-}\right)$, ammonium $\left(\mathrm{NH}_{4}{ }^{+}\right)$, and phosphate $\left(\mathrm{PO}_{4}{ }^{2-}\right)$. A separate aliquot of each filtrate sample was filtered with blood serum filters (Porex PlasticEvacuated 6211; Porex Corp., Fairburn, GA) with an effective filtration of $10 \mu \mathrm{m}$ to determine total soluble $\mathrm{N}$ (TN, organic and inorganic forms) with a $\mathrm{N}$ analyzer (LECO TruSpec CHN 630; LECO Corp., Saint Joseph, MI). Three additional bags for each moisture level treatment were analyzed for moisture content by weighing the contents of the bag, drying in an oven at $110^{\circ} \mathrm{C}$ for $3 \mathrm{~d}$, and weighing again. Nutrient concentrations determined by ion chromatography were converted to mass (mg) of each nutrient using the volume of water applied for the extraction process $(350 \mathrm{~mL})$ and the volume of water measured as moisture content.

Four replications of each treatment combination were subsequently removed from each chamber at $14,30,90$, and $180 \mathrm{~d}$ after the substrates were mixed and subjected to the same extraction and nutrient analysis described previously. Likewise, three bags for each temperature and moisture level treatment combination were measured for percent moisture content.

Data were subjected to analysis of variance and correlation analysis, when appropriate, using statistical software (SAS v9.3; SAS Institute, Cary, NC). Data were plotted as means with error bars representing the 95\% confidence interval (CI) about the mean, using graphing software (SigmaPlot 12.5; SYSTAT Software, Inc., Chicago, IL).

\section{Results and Discussion}

Moisture content of bagged substrates was reported in a previous experiment conducted simultaneously with the one described herein (Jeong and Altland, 2017). Summarizing briefly from that previously reported data, moisture content of the bagged substrates changed over time (Fig. 1). There were significant interactions between IMC and day for bags stored in both 20 and $40{ }^{\circ} \mathrm{C}$ chambers $(P<0.0001$, data not shown). Over the duration of the experiment, moisture in bags with $25 \%, 45 \%$, and $65 \%$ IMC stored at $20{ }^{\circ} \mathrm{C}$ were reduced by $17 \%, 28 \%$, and $13 \%$, respectively, whereas those stored at $40{ }^{\circ} \mathrm{C}$ were reduced by $21 \%, 41 \%$, and $60 \%$, respectively.

Substrate $\mathrm{pH}$ was affected by the interaction between day and IMC as well as fertilizer type and IMC in the $20^{\circ} \mathrm{C}$ environment, and the three-way interaction of the main effects in the $40{ }^{\circ} \mathrm{C}$ environment (Table 1). The fertilizer by IMC interaction in the $20{ }^{\circ} \mathrm{C}$ chamber was reflected primarily by the impact IMC had on substrate $\mathrm{pH}$ (Fig. 2). Substrate $\mathrm{pH}$ for both storage temperatures with $20^{\circ} \mathrm{C}$
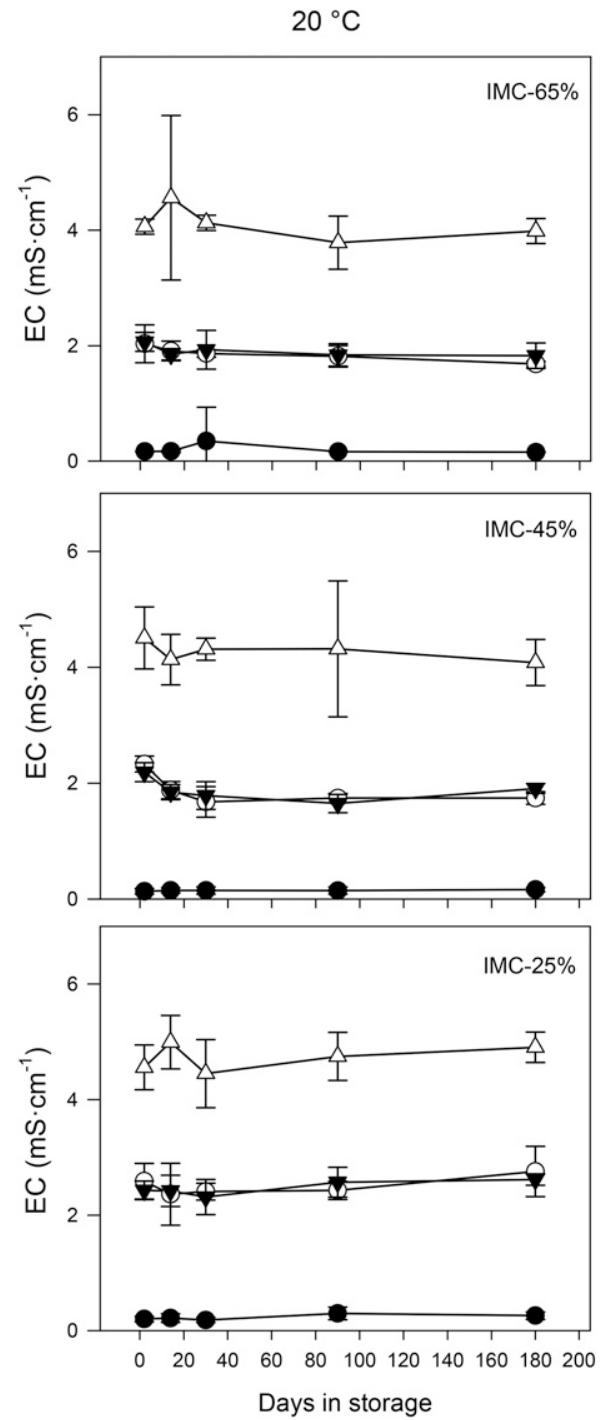

$25 \%$ IMC ranged between $\mathrm{pH} 4.1$ and 5.4 (with a few exceptions in NFC), whereas those with $45 \%$ IMC ranged between 4.9 and 6.5 , and those with $65 \%$ IMC ranged between 5.2 and 7.0 (Fig. 2). Although there was a higher order three-way interaction between day, IMC, and fertilizer type in $40-^{\circ} \mathrm{C}$ chambers, $\mathrm{pH}$ response to IMC was similar to the $20{ }^{\circ} \mathrm{C}$ chamber, with the lowest $\mathrm{pH}$ in bags with $25 \%$ IMC. A similar response to IMC occurred in bagged substrates fertilized with a CRF (Jeong and Altland, 2017). Dissolution of dolomitic limestone added to potting mixes can cause a gradual increase in media $\mathrm{pH}$ over time (Carlile, 2004). The calcium and magnesium carbonate $\left[\mathrm{CaMg}\left(\mathrm{CO}_{3}\right)_{2}\right]$ in dolomitic lime dissociates in water to form exchangeable $\mathrm{Ca}^{2+}$ and $\mathrm{Mg}^{2+}$, as well as carbon dioxide and additional water molecules (Lindsay, 1979). Although water is
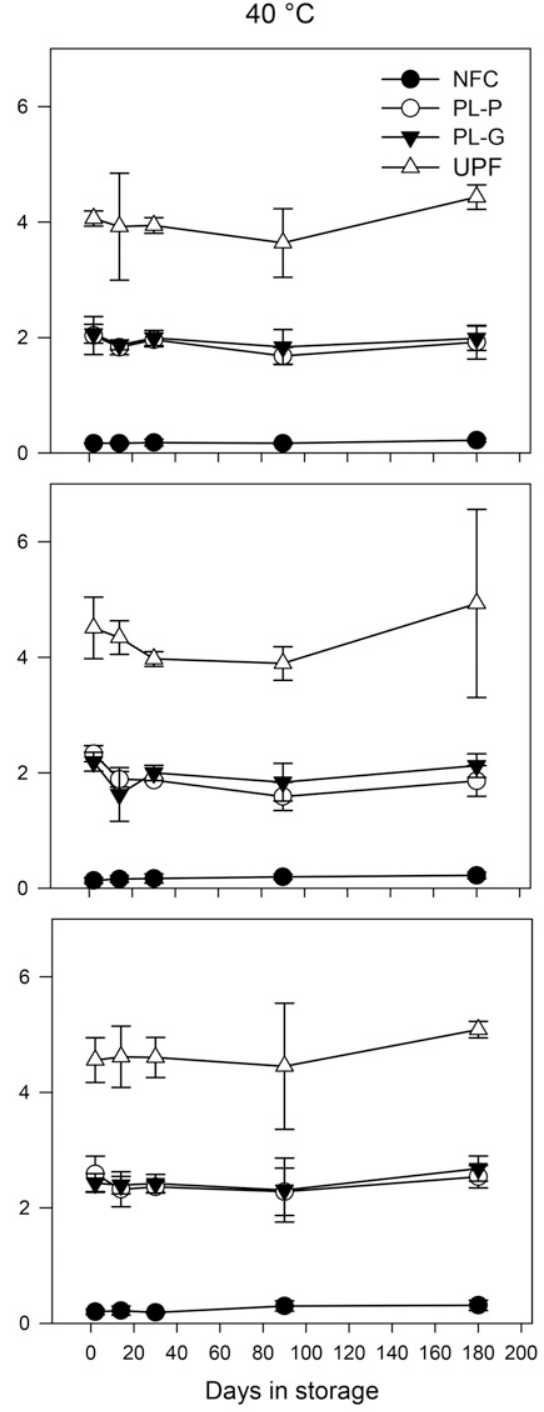

Fig. 3. Substrate electrical conductivity (EC) of a bagged substrate composed of 60 sphagnum peat : 30 bark : 10 perlite by volume with $5.5 \mathrm{~g} \cdot \mathrm{L}^{-1}$ dolomitic limestone. Substrates were either not amended with fertilizer [(nonfertilized control (NFC)], or amended with $0.59 \mathrm{~kg} \cdot \mathrm{m}^{-3} \mathrm{~N}$ of a poultry litter (PL) (microSTART60, 3N-0.9P-2.5K) that was either pelletized (PL-P) or ground (PL-G), or amended with an uncoated prilled fertilizer (UPF, $15 \mathrm{~N}-6.5 \mathrm{P}-12.5 \mathrm{~K}$; Yara). Substrates had initial moisture contents (IMCs) of $65 \%$ (top), $45 \%$ (middle), or $25 \%$ (bottom) and were stored at either $20{ }^{\circ} \mathrm{C}$ (left) or $40{ }^{\circ} \mathrm{C}$ (right). Error bars represent a 95\% confidence interval about the mean. 
necessary for the reaction to occur, there is no literature addressing the impact of moisture level in soils or soilless substrates on lime reactivity. Although not compared statistically, substrate $\mathrm{pH}$ response to IMC followed a similar pattern in 20 and $40{ }^{\circ} \mathrm{C}$ growth chambers. Both PL fertilizer treatments resulted in $\mathrm{pH}$ similar to or lower than the NFC. Bi et al. (2010) likewise showed that two noncomposted PL-based organic fertilizers had similar or lower $\mathrm{pH}$ compared with NFCs in container-grown marigold. Poultry litter particle size had no effect on substrate $\mathrm{pH}$, as means and 95\% CI bars for both treatments (PL-P and PL-G) overlapped throughout the experiment in all six IMC and temperature conditions. The UPF treatment reduced $\mathrm{pH}$ throughout the experiment, and means were similar to or lower than all other treatments. Fertilizer effects on $\mathrm{pH}$ were likely due to the potential acidity of each product. A similar reaction occurred in a related study, in that substrates fertilized with a CRF had a similar or lower substrate $\mathrm{pH}$ compared with NFCs (Jeong and Altland, 2017). Although the fertilizers used in this study do not provide a labeled potential acidity or basicity, most agricultural fertilizers are acidic (Hershey, 1991; Jeong et al., 2016).

Day, IMC, and fertilizer type affected substrate EC in two-way interactions, but not three-way interactions, at both 20 and $40{ }^{\circ} \mathrm{C}$ (Table 1). EC of the NFC substrate ranged from 0.13 to $0.35 \mathrm{mS} \cdot \mathrm{cm}^{-1}$ (Fig. 3). The two PL fertilizers had higher EC throughout the experiment (1.59-2.76 $\mathrm{mS} \cdot \mathrm{cm}^{-1}$ ) than NFC. Similar to $\mathrm{pH}, \mathrm{PL}$ particle size had no effect on EC, as the 95\% CI bars overlapped for the two treatments throughout the experiment. Electrical conductivities of PL-amended substrates were similar to those reported by $\mathrm{Bi}$ et al. (2010) when using similar amendment rates $\left(0.518 \mathrm{~kg} \cdot \mathrm{m}^{-3} \mathrm{~N}\right)$ of a different poultry fertilizer. The UPF treatment consistently resulted in higher EC (3.64-5.09 $\left.\mathrm{mS} \cdot \mathrm{cm}^{-1}\right)$ than both PL treatments and the NFC. This indicates that the salts in UPF were quickly dissolved and readily available in soil solution, whereas salts from PL were released more slowly over time. Using the same brand of PL fertilizer, Mattson (2014) observed EC values of $0.6 \mathrm{mS} \cdot \mathrm{cm}^{-1}$ in PL-fertilized substrates, compared with an EC of $1.4 \mathrm{mS} \cdot \mathrm{cm}^{-1}$ in containers fertilized with an industry standard $21 \mathrm{~N}-2.2 \mathrm{P}-8.3 \mathrm{~K}$ water soluble fertilizer. Mattson (2014) goes on to warn that EC from organic fertilizers such as those based on PL can be difficult to interpret because water-soluble nutrients (salts) from these products become available more slowly over time; and therefore, low EC does not necessarily reflect low fertility.

Inorganic $\mathrm{N}\left(\mathrm{IN}, \mathrm{NO}_{3}{ }^{-}+\mathrm{NH}_{4}{ }^{+}\right)$recovered in substrates was affected by the three-way interaction between day, fertilizer type, and IMC in both 20 and $40{ }^{\circ} \mathrm{C}$ (Table 1). Percent IN recovery of PL and NFC treatments was at or near $0 \%$ throughout the experiment in all of the temperature and IMC treatment combinations (Fig. 4). Inorganic $\mathrm{N}$ recovery from UPF-treated substrates was higher than PL or NFC substrates. Although IN recovery from UPF-treated substrates was somewhat erratic over time and substrate conditions, all six of the IMC and temperature combinations resulted in $\approx 40 \%$ recovery by the conclusion of the experiment.

Total $\mathrm{N}$ was affected by the three-way interaction between IMC, fertilizer type, and day in both temperature conditions (Table 1). Percent TN recovered was at or near $0 \%$ for the NFC substrates, as expected (Fig. 5). The two PL treatments were again similar to each other throughout the experiment in all six IMC and temperature treatment combinations. Percent TN recovered from both PL treatments never exceeded $50 \%$. Recovery from PL substrates was slightly higher with $25 \%$ IMC at both 20 and $40^{\circ} \mathrm{C}$. Percent TN
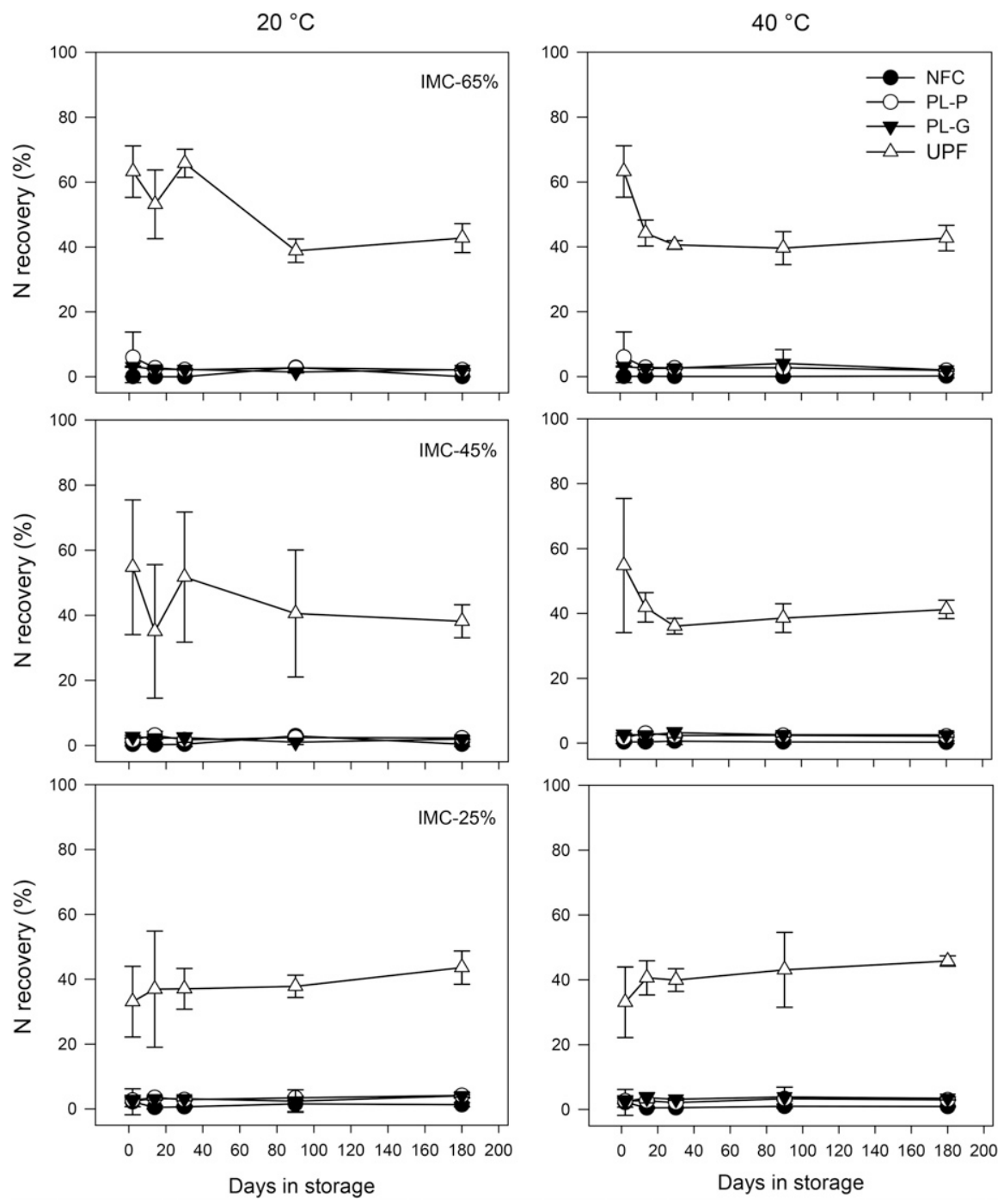

Fig. 4. The recovered water extractable inorganic nitrogen $\left(\mathrm{NO}_{3}{ }^{-}, \mathrm{NH}_{4}{ }^{+}\right)$from a substrate composed of 60 sphagnum peat : 30 bark : 10 perlite by volume with $5.5 \mathrm{~g} \cdot \mathrm{L}^{-1}$ dolomitic limestone. Data are expressed as mean percentage of the total mass of $\mathrm{N}$ applied via each fertilizer product. Substrates were either not amended with fertilizer [nonfertilized control (NFC)], or amended with $0.59 \mathrm{~kg} \cdot \mathrm{m}^{-3} \mathrm{~N}$ of a poultry litter (PL) (microSTART60, 3N-0.9P-2.5K) that was either pelletized (PL-P) or ground (PL-G), or amended with an uncoated prilled fertilizer (UPF, $15 \mathrm{~N}-6.5 \mathrm{P}-12.5 \mathrm{~K}$; Yara). Substrates had initial moisture contents (IMCs) of $65 \%$ (top), $45 \%$ (middle), or $25 \%$ (bottom) and were stored at either $20{ }^{\circ} \mathrm{C}$ (left) or $40{ }^{\circ} \mathrm{C}$ (right). Error bars represent the $95 \%$ confidence interval about the mean. 
$20^{\circ} \mathrm{C}$
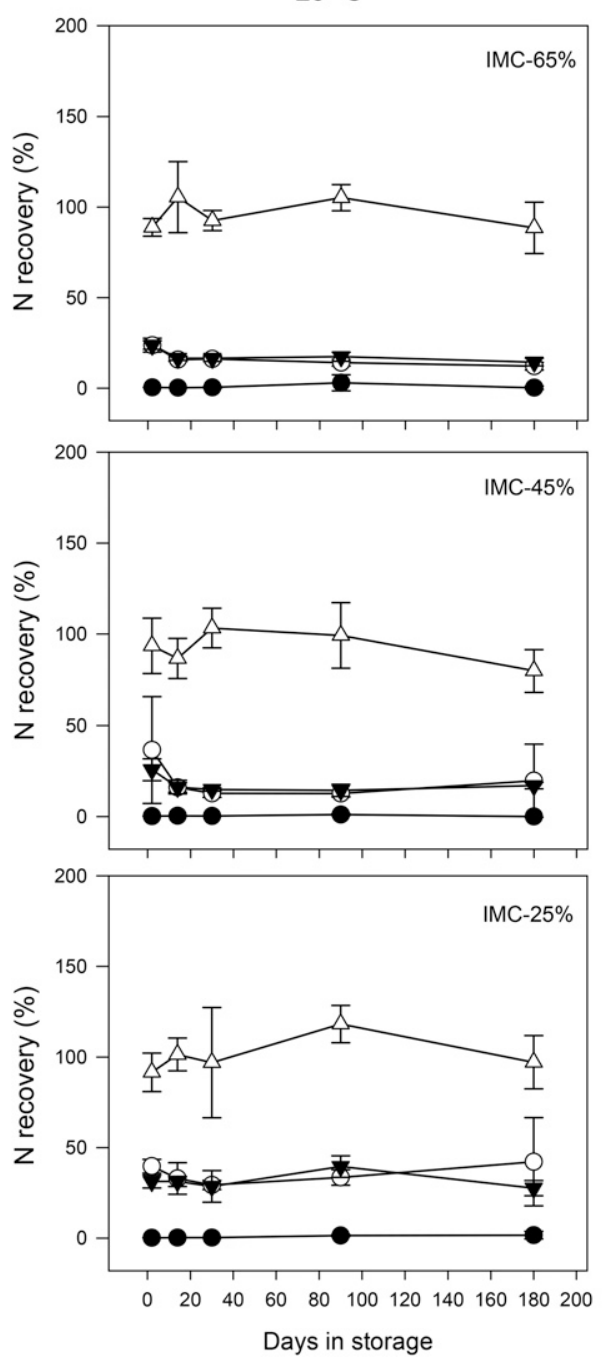

$40^{\circ} \mathrm{C}$
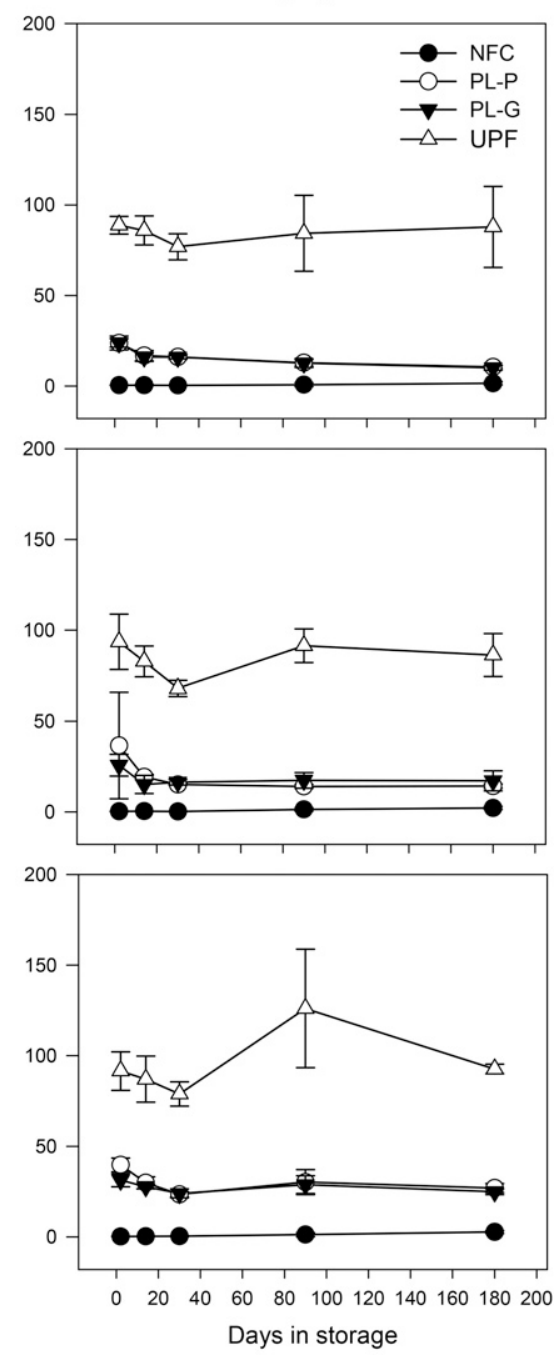

Fig. 5. The recovered water extractable total nitrogen $\left(\mathrm{NO}_{3}{ }^{-}, \mathrm{NH}_{4}{ }^{+}\right.$, and organic nitrogen) from a substrate composed of 60 sphagnum peat : 30 bark : 10 perlite by volume with $5.5 \mathrm{~g} \cdot \mathrm{L}^{-1}$ dolomitic limestone. Data are expressed as mean percentage of the total mass of $\mathrm{N}$ applied via each fertilizer product. Substrates were either not amended with fertilizer [nonfertilized control (NFC)], or amended with 0.59 $\mathrm{kg} \cdot \mathrm{m}^{-3} \mathrm{~N}$ of a poultry litter (PL) (microSTART60, 3N-0.9P-2.5K) that was either pelletized (PL-P) or ground (PL-G), or amended with an uncoated prilled fertilizer (UPF, $15 \mathrm{~N}-6.5 \mathrm{P}-12.5 \mathrm{~K}$; Yara). Substrates had initial moisture contents (IMCs) of $65 \%$ (top), $45 \%$ (middle), or $25 \%$ (bottom) and were stored at either $20^{\circ} \mathrm{C}$ (left) or $40{ }^{\circ} \mathrm{C}$ (right). Error bars represent the $95 \%$ confidence interval about the mean.

analysis using the CHN analyzer. Samples for IN analysis were filtered to $0.7 \mu \mathrm{m}$, which specifically detects and quantifies ionic compounds such as $\mathrm{NO}_{3}{ }^{-}$and $\mathrm{NH}_{4}{ }^{+}$. Samples for $\mathrm{TN}$ analysis were filtered to $10 \mu \mathrm{m}$ as specified for the $\mathrm{CHN}$ equipment. The $\mathrm{CHN}$ analyzer uses combustion and thermal conductivity detection to quantify total $\mathrm{N}$, and thus, accounts for all $\mathrm{N}$ dissolved or suspended in the solution. Bacteria range in size from 0.5 to $5 \mu \mathrm{m}$, and thus, would have easily passed through filtration used for TN analysis. Myrold and Posavatz (2007) showed that bacteria, not fungi, had greater potential to immobilize $\mathrm{NO}_{3}{ }^{-}$in forest and meadow soils. Likewise, Güsewell and Gessner (2009) demonstrated that bacterial-immobilization of $\mathrm{N}$ was greater than fungal-immobilization at $\mathrm{N}: \mathrm{P}$ ratios less than 5.0, similar to those used in our experiment (N:P ratios ranged from 2.3 to
3.3). It is, therefore, reasonable to expect that $\mathrm{N}$ immobilized by bacteria would have been excluded by IN analysis but included in the TN results.

Percentage of applied $\mathrm{P}$ recovered was affected by the three-way interaction of IMC, fertilizer type, and day for both 20 and $40{ }^{\circ} \mathrm{C}$ conditions (Table 1). Percent $\mathrm{P}$ recovered from NFC substrates was at or near $0 \%$, as expected (Fig. 6). The effect of particle size of PL fertilizers (PL-P vs. PL-G) was erratic with no consistent trend with respect to one treatment being similar, greater, or less than the other for $\% \mathrm{P}$ recovered. With few exceptions, $\% \mathrm{P}$ recovered from the UPF-amended substrates was similar to or greater than all other treatments. Percentage of recovered $\mathrm{P}$ in the UPF treatment decreased from day 2 through day 30 in all IMC and temperature combinations. This decrease in $\% \mathrm{P}$ recovered could be due to chemical reactions between phosphates from the fertilizer and other metals such as $\mathrm{Ca}, \mathrm{Mg}$, and $\mathrm{Fe}$ in the substrate forming water-insoluble complexes. A more likely reason for the reduction in $\% \mathrm{P}$ recovery rates is microbial $\mathrm{P}$ immobilization. Handreck (1996) showed that $40 \%$ to $50 \%$ of extractable $\mathrm{P}$ was reduced in the first $5 \mathrm{~d}$ of a substrate incubation study solely as a function of microbial immobilization. The N:P ratio of all the $\mathrm{N}$ and $\mathrm{P}$ not recovered from the UPF substrates ranged from 1.2 to 5.8 with an overall mean of 2.8 (data not presented). The $\mathrm{N}: \mathrm{P}$ ratio of bacteria is 4.7 on a dry weight basis (Brookes et al., 1984; Todar, 2012), which further corroborates the likelihood that unrecovered $\mathrm{P}$ in the UPF treatments was due to microbial immobilization.

In summary, there are several conclusions that can be made from using PL fertilizer in bagged potting mix. First, PL particle size had no effect on any of the measured chemical properties of the stored substrates. Particle size of the PL-P fertilizer used in this study was sufficiently small and uniformly distributed throughout the growing media to affect the nutrient content of the bagged potting mix without further particle size reduction.

Second, values for percent IN recovered (near zero) in the PL-fertilized substrates are not reflective of true plant-available N. Previous unpublished research with the same PL-fertilized potting mix used in this research showed that plants grew well compared with conventionally fertilized substrates, and thus would have access to some form of $\mathrm{N}$ (K. Jeong, personal observation). Nitrate and $\mathrm{NH}_{4}{ }^{+}$analyses with laboratory-grade analytical equipment or field-grade probes should not be used to evaluate the quality or characteristics of PL-fertilized potting mix. By contrast, EC and TN provided data more consistent with previous experience (K. Jeong, personal observation). EC values for PL-fertilized potting mixes ranged from 1.59 to $2.76 \mathrm{mS} \cdot \mathrm{cm}^{-1}$ throughout the experiment. Although there are no established standards for EC in bagged potting mix, an $\mathrm{EC}$ of $2.00 \mathrm{mS} \cdot \mathrm{cm}^{-1}$ is generally considered to be ideal (several commercial sources, personal communication). Percentage of TN recovered from the PL-fertilized potting mix ranged from $10 \%$ to $42 \%$ across treatments. Furthermore, these TN values remained relatively stable over time within an IMC and temperature treatment combination (Fig. 5). Unlike the nutrient load from a CRF-fertilized potting mix that increased steadily over time (Jeong and Altland, 2017), nutrient loads in PLfertilized potting mix were more stable over the $180 \mathrm{~d}$ storage period.

Another practical application of this research is the potential use of filtering techniques to quantify $\mathrm{N}$ forms in soilless substrates. The different filtering techniques used in this research before the IC and $\mathrm{CHN}$ analyses were not deliberate but merely followed the standard protocols for each laboratory system. Our results suggest that filtration to include or exclude bacteriaimmobilized $\mathrm{N}$, as well as which analytical 
$20^{\circ} \mathrm{C}$
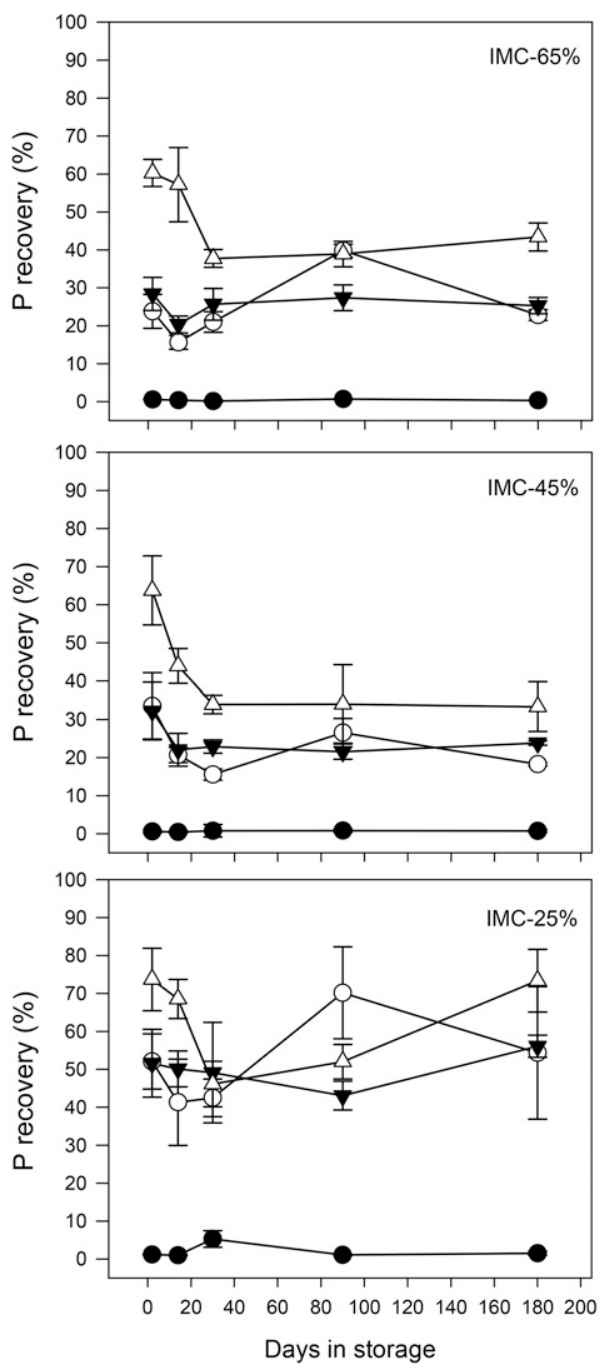

$40^{\circ} \mathrm{C}$
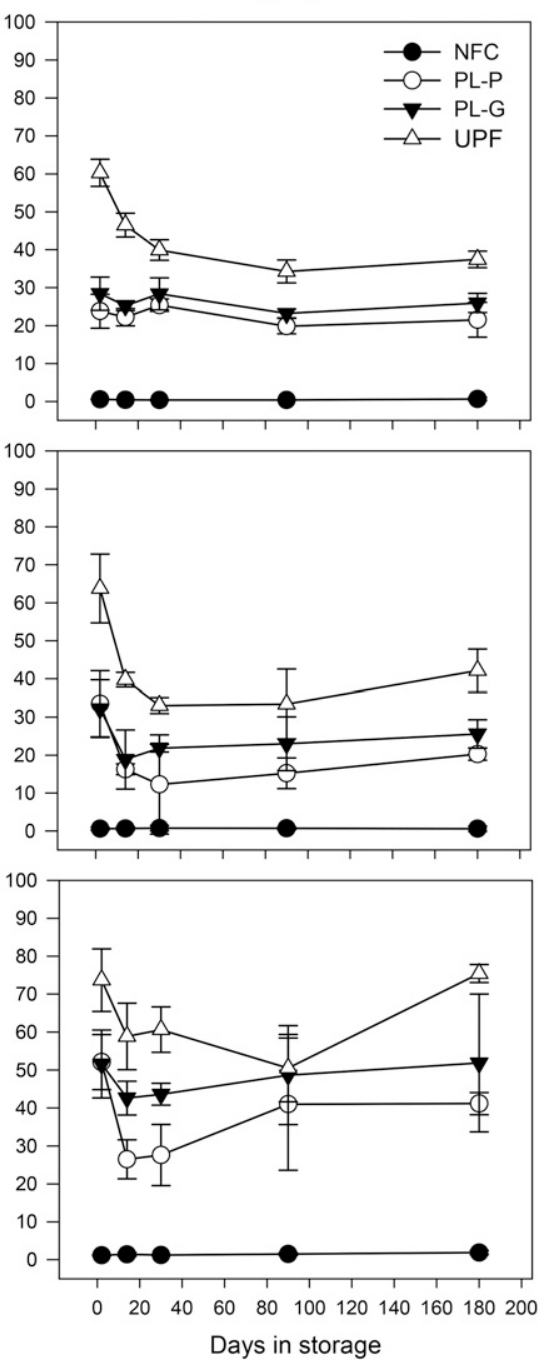

Fig. 6. The percentage of recovered water extractable phosphorus (P) from a substrate composed of 60 sphagnum peat : 30 bark : 10 perlite by volume with $5.5 \mathrm{~g} \cdot \mathrm{L}^{-1}$ dolomitic limestone. Data are expressed as the mean percentage of the total mass of $\mathrm{P}$ applied in each fertilizer product. Substrates were either not amended with fertilizer [nonfertilized control (NFC)], or amended with $0.59 \mathrm{~kg} \cdot \mathrm{m}^{-3} \mathrm{~N}$ of a poultry litter (PL) (microSTART60, 3N-0.9P-2.5K) that was either pelletized (PL-P) or ground (PL-G), or amended with an uncoated prilled fertilizer (UPF, $15 \mathrm{~N}-6.5 \mathrm{P}-12.5 \mathrm{~K}$; Yara). Substrates had initial moisture contents (IMCs) of $65 \%$ (top), $45 \%$ (middle), or $25 \%$ (bottom) and were stored at either $20{ }^{\circ} \mathrm{C}$ (left) or $40{ }^{\circ} \mathrm{C}$ (right). Error bars represent a $95 \%$ confidence interval about the mean.

technique (IC vs. CHN) is used, can be used to better understand the forms of $\mathrm{N}$ in soilless substrates. Further research is needed to understand how organic or bacteriaimmobilized $\mathrm{N}$ become available for plant uptake.

The objective of this research was to determine chemical changes ( $\mathrm{pH}$ and EC) and nutrient availability from an organic PL fertilizer incorporated into a bagged potting mix during storage. Our data show PL fertilizer provided a stable source of $\mathrm{N}$ in bagged potting mix over a range of IMC and storage temperatures $\left(20\right.$ and $40{ }^{\circ} \mathrm{C}$ ), with little change in total $\mathrm{N}$ released over time. These data further show that the PL fertilizer used in its commercially available particle size provided a suitable source of nutrients for bagged potting mixes subjected to prolonged storage before use.

\section{Literature Cited}

Agehara, S. and D.D. Warncke. 2005. Soil moisture and temperature effects on nitrogen release from organic nitrogen sources. Soil Sci. Soc. Amer. J. 69:1844-1855.

Anonymous. 2017. Walmart launches project Gigaton to reduce emissions in company's supply chain. 23 May 2018. <http://news.walmart. com/2017/04/19/walmart-launches-projectgigaton-to-reduce-emissions-in-companys-supplychain $>$.
Bi, G., W.B. Evans, J.M. Spiers, and A.L. Witcher. 2010. Effects of organic and inorganic fertilizers on marigold growth and flowering. HortScience 45:1373-1377.

Brookes, P.C., D.S. Powlson, and D.S. Jenkinson. 1984. Phosphorus in the soil microbial biomass. Soil Biol. Biochem. 16:169-175.

Burnett, S.E., N.S. Mattson, and K.A. Williams. 2016. Substrates and fertilizer for organic container production of herbs, vegetables, and herbaceous ornamental plants grown in greenhouses in the United States. Scientia Hort. 208:111-119.

Carlile, W.R. 2004. Changes in organic growing media during storage. Acta Hort. 648:153159.

Chae, Y.M. and M.A. Tabatabai. 1986. Mineralization of nitrogen in soils amended with organic wastes. J. Environ. Qual. 15:193198.

Fisher, P., J. Huang, M. Paz, and R. Dickson. 2016. Having success with organic growing mixes. GrowerTalks 79(10):68-72.

Granderson, D. 2015. Packaged facts: In \$6 billion lawn and garden supplies market, demand for organic products on the rise. 23 May 2018. $<$ http://www.prnewswire.com/news-releases/ packaged-facts-in-6-billion-lawn-and-gardensupplies-market-demand-for-organic-productson-the-rise-300133591.html>.

Griffin, T.S. and C.W. Honeycutt. 2000. Using growing degree days to predict nitrogen availability from livestock manures. Soil Sci. Soc. Amer. J. 64:1876-1882.

Güsewell, S. and M.O. Gessner. 2009. N:P ratios influence litter decomposition and colonization by funge and bacteria in microcosms. Funct. Ecol. 23:211-219.

Handreck, K.A. 1996. Phosphorus immobilization in wood waste-based potting media. Commun. Soil Sci. Plant Anal. 27:2295-2314.

Hershey, D.R. 1991. Acidity and basicity of fertilizers. J. Chem. Educ. 68:642.

Jeong, K. and J.E. Altland. 2017. Initial substrate moisture content affects chemical properties of bagged substrates containing controlled release fertilizer at two different temperatures. HortScience 52:1429-1434.

Jeong, K., P.V. Nelson, C.E. Niedziela, Jr., and D.A Dickey. 2016. Effect of plant species, fertilizer acidity/basicity, and fertilizer concentration on $\mathrm{pH}$ of soilless root substrate. HortScience 51:15961601.

Lindsay, W.L. 1979. Chemical equilibria in soils: Carbonate equilibria. The Blackburn Press, Caldwell, NJ

Malhi, S.S. and W.B. McGill. 1982. Nitrification in three Alberta soils: Effect of temperature, moisture and substrate concentration. Soil Biol. Biochem. 14:393-399.

Mattson, N. 2014. Comparing substrate fertilizer amendments for spring bedding plants. Greenhouse Grow. Mag. 32(13):48-54.

Myrold, D.D. and N.R. Posavatz. 2007. Potential importance of bacteria and fungi in nitrate assimilation in soil. Soil Biol. Biochem. 39:1737-1743.

Todar, K. 2012. Todar's online textbook of bacteriology. 23 May 2018. <http://textbookofbacteriology.net/ nutgro.html $>$.

Wander, M. 2015. Organic potting mix basics. eOrganic 3442. 23 May 2018. <http://articles. extension.org/pages/20982/organic-potting-mixbasics>. 